\title{
Factors Militating against Successful Implementation of Computer Studies in 9-Year Universal Basic Education (UBE) Programme
}

\author{
Garba Suleiman \\ Department of Computer Science \\ FCT College of Education, Zuba, Nigeria \\ Email: sulgarba@gmail.com
}

\author{
Solomon A. Adepoju \& John K. Alhassan \\ Department of Computer Science, Federal University of Technology Minna, Nigeria \\ sa.adepoju@gmail.com, jkalhassan@futminna.edu.ng
}

\begin{abstract}
The application of Information and Communication Technology which is shaping and changing the world socially, educationally and economically cannot be over emphasized. In view of that, this paper looks at the factors militating against successful implementation of computer studies in 9-year Universal Basic Education (UBE) programmes. Five UBE schools were randomly selected for the research. Two research questions were postulated to guide the conduct of the research and t-test analysis was used for testing the hypotheses. The findings showed that there is positive perception by the students on factors militating against successful implementation of 9-year UBE programme. Based on the findings, some recommendations were made: provision of qualified teachers, instructional materials, provision of laboratories and so on in order to improve and ensure effective and efficient implementation of the 9-year Universal Basic (UBE) programme.
\end{abstract}

Index Terms-Militating, Technology, Teaching, Learning, Implementation, Provision

\section{INTRODUCTION}

Technology is the practical application knowledge especially in a particular area to achieve some results. The state of any country or nation's development depends largely on the technological attainment, that is the greater the level of technological development advancement, the rapid the pace of development, hence, the training of human resources irrespective of the gender should be given higher priority. [11] stated that, following the fast progress of technology, in recent years, and its wide integration in many human activities, education has been changed as well. From mainly a teaching discipline in the past, it transformed into an integrated learning environment that uses various technology tools and solution for enhanced understanding. Also, [16] view the advent of Information and
Communication Technologies and internet make the teaching and learning process simple and extend to the birth of e-learning. Recognizing the impact of a new technologies in the workplace and everyday life, today's educational institutions try to restructure their academic programs and classroom facilities, in order to minimize the teaching and learning technology gap between today and future. This restructuring process requires effective integration of technologies into existing content in order to provide learners with knowledge of specific subject areas, to promote meaningful learning and to enhance professional productivity. In view of this, the use and learning of computer studies is imperative at nursery or primary for any nation to meet up the changing world. In addition, [14] stated that there are many advantages in using technology in educational settings, for example, they make the learner more interested about the subject, they decrease time, and they provide opportunities to learn in non-traditional ways.

According to [17] computers have affected our lives in many ways, in the field of education, computers are perceived as an important tool to transform how we teach, learn, evaluate learning goals and communicate information Therefore, the role of computer and technology in our day to day activities in the present technology cannot be over-emphasized. Some of these roles are:

i. Helps pupils to apply scientific knowledge and concepts to better their environment. It also let students to be more involved in the learning process and teachers using interactive multimedia software and hypermedia.

ii. Helps pupils to use their brain and hands in vocational and technical areas of specialization

iii. The application of computer in our daily office works such as planning, budgeting and other office routine that do take time to implement, hence with the use of computer it can be urgently implemented. 
iv. It also enhances business transactions such as salary preparation, invoicing, money transaction which could be easily done within a short period of time

v. With advent of computer and technology, it has greatly enhances health facilities and access to modern medical care. Telemedicine uses technology to deliver medical services to the point of need. It encompasses all the health care, education, information and administrative services that can be transmitted over distances by telecommunication technologies.

vi. In the field of communication, computer and technology has enhanced the transmission of messages of information from one person to another. It includes the usage of fax, video conferencing and the internet. In addition, it is also used in the booking of flights (i.e. seat reservation) and road traffic control, where the computer is used to maintain and control traffic; especially at congested areas.

On recognition of these facts and others, most institutions in the country now introduce computer studies in their curriculum and in the running of their activities. Therefore, the computer operates on the basis of input-process-output. It is common to hear garbage in, garbage out. If you input garbage, the computer will process it as such give you garbage as output.

From the above one can deduce that, computer is an electronic device that is capable of accepting data as input, process the data and gives output as information.

\section{9-YEAR UNIVERSAL BASIC EDUCATION (UBE) COMPUTER STUDIES - AIMS AND OBJECTIVES}

Computer education is a system of skills acquisition by the use of computer to solve problem. Computer education is seen as a subject organizes to enable people to understand the function, uses and limitations of computer and to provide an opportunity for the study of the modern method of information processing. It is an academic subject because it encourages an understanding of the studies implication.

In 1998, the Federal Government of Nigeria pursue with highest commitment a policy of free and compulsory education known as Universal Basic Education (UBE), hence computer education was entrenched in 6-3-3-4 system of education with the following aims and objectives to:

1. Produce manpower that can be trained on both software and hardware development.

2. Produce computer engineers that can repair and service faulty components.

3. Produce experts that can make use of computer in the field of pure and applied science, engineering and research work.

4. Develop scientific attitude and scientific way of planning, observing and working through experiences in problem solving.
5. Acquisition of literacy, numerical like skills and values for lifelong education and useful living.

6. Develop an appreciation of the contribution of computer to man and society and its importance to the future.

Today, the world is continuously fashioned or dominated by Information communication technology (ICT), which is tremendously changing our world and culture. According to [13] ICT encompasses science, technology as well as social sciences on an integrated platform which in turn coordinates and monitors every research and development activities o make this society aware of the present trends. The computer is a major component of ICT. It is tool that have singularly and dramatically continued to change the behavioural patterns of people and corporate entities by determining the way they socialize, learn shop, conduct business, communicate and interact for multi-dimensional mutual reasons. In 2001, the Federal Government approved a National Information Technology Policy and the establishment of the National Information Technology Development (NITDA), with the mission for education , creation of wealth, job creation etc. In response to these, the Federal Government of Nigeria in 2006 through Nigeria Educational Research and Development Council (NERDC) and relevant educational stakeholders introduce the 9- year basic education programme which can be summarized to aim at value reorientation, poverty eradication and education to empower the people. It becomes imperative that the existing curricula for primary and junior secondary should be reviewed, restructure and re-aligned to fit into 9-year basic education programme.

In the new curriculum, computer studies is one of the core subjects at all levels of basic education in order to advance Basic Technology for self reliance and key into the emerging global village that the world is moving to.

To meet up these changing needs of the society, computer is beneficial to the students by:

- Given the right condition, computer could be beneficial to students in promoting, encouraging and facilitate students to have access to information independently if it is used properly

- It also assist students with special needs to be able to realize and achieve their goals by working at their own rate.

- Creating greater interest and enthusiasm for learning among the students

- Using computer devices in accessing relevant information from the internet

- Allowing the learners to have exposure to varieties of vocational and work skills

- $\quad$ Promoting students with profound multiple learning disabilities to be able to communicate easily

- Using voice communication to gain self confidence and able to mixed socially in schools and their communities and 
- Having the potential to significantly increase access to guidance services, freeing it from constraints of time and space [12].

- Providing the learners with additional resources to handle resource based learning easily.

In addition, [9] itemized the benefit of ICT to the students which include:

- Computers can improve independent access for students to education

- Students with special educational needs are able to accomplish tasks working at their own.

- Create greater enthusiasm for learning amongst students,

- Visually impaired students using the internet can access information alongside their sighted peers.

- Give greater exposure to vocational and workforce skills for students,

- Students with profound and multiple learning difficulties can communicate more easily.

- Students using voice communication aids gain confidence and social credibility at school and in their communities.

- Increased ICT confidence amongst students motivates them to use the Internet at home for schoolwork and leisure interests.

- Provide distance learners country-wide with online educational materials.

- Provide learners with additional resources to assist resource-based learning

Hence, computer education curriculum for Basic Education schools in Nigeria takes into account the convergence phenomena in technology, global trends and the characteristics of information age and knowledge based and ICT as driving force behind economic development.

To meet the objectives of 9-year basic education, the aims and objectives of 6-3-3-4 systems was incorporated and reviewed to meet the modern challenges of computer education. Reference [7] curriculum, the learners under the 9-year basic education are expected to:

1. Acquire basic computer skills such as the use of keyboard, mouse and operating systems.

2. Use the computer to facilitate learning electronically.

3. Develop responsible level of competence in ICT applications that will engender entrepreneurial skills.

From the foregoing, one can see that the Universal Basic Education programme in Nigeria is an expression of government commitment to the development of computer education in order to eradicate poverty, create job opportunities and in general to meet up with the trends of global changes in technology.

\section{LITERATURE REVIEW}

Educators and prominent government policy makers have acknowledged that the education system in Nigeria is in dire need of reforms. In Nigeria public school structure, education is not supported by any ICT based systems. And wherever ICT system exists, it is marred by several challenges ranging from power failure; outdated systems to scarcity of ICT qualified educators.

[15] observed that ICT provides the communication network that facilitates the expansion of products, ideas and resources among nations and among people regardless of geographical location. However, Nigerian government believes and has seen hard evidence that ICT can play a major role in education and economy development as witnessed in other developed countries

In any educational system, the level of available resources places a restriction on the degree to which any new subject can be introduced into the school curriculum, especially where only the most basic facilities have so far been provided. But ICT is of such importance to the future industrial and commercial health of a country that investment in the equipment, teacher education, and support services necessary for the effective delivery of an ICT- based curriculum should rank high in any set of government priorities. The curriculum takes account of these resource issues and specifies minimum requirements for effective delivery in different circumstance. One of the millennium development goals of the Nigerian nation in the education industry is that schools must be Information and Communication Technology (ICT) compliant and in response to this goal, government procured and distributed computers to schools. According to [1] the qualifications of the majority of the teachers are far from being satisfactory due to lack of exposure to college curriculum that does not cater for ICT training. The teachers have poor practical skills in ICT usage since the majority of them could not even use the basic software in computers for the delivery of their lessons and indications are that the teachers lack the necessary skills and knowledge of computers in basic software usage. Administrative support could also take the form policy enactments where ICT competence is made mandatory for school teachers. This can be an effective measure to improving teachers' ICT knowledge and skills [1]; therefore, due to the existing constraints in computer education implementation, remedial action needs to be taken. Reference [6] proposes the need to put in place measures to ensure that adequate access to technical support is provided. [6] Also established that teachers needed training which should be offered on a continuous, rather than a one off basis so that their computer knowledge is upgraded over time.

Reference [5] ICT skills or competence are broadly investigated phenomena, often in order to support practical policy- making and teacher training. But with a lot of hindrances in the implementation of the ICT focused programmes, more searches need to be carried out, hence the current aimed at investigating the teacher competences in ICT with a view to inform decision making. Reference [8] the world is moving rapidly into 
digital media and information and that the role of ICT in education is becoming more and more important and this importance will continue to grow and develop in the $21^{\text {st }}$ century,

Since we live in information society, Reference [10] everyone is expected to be ICT literate which entails;

\section{Awareness}

As you study ICT (computers), you will become aware of their importance, versatility, pervasiveness, and their potential for good and ill in our society

\section{Knowledge}

You will learn what computers are and how they work. This requires learning some technical jargons that will help you deal with the computer and with people that work with computers. and

\section{Interaction}

This implies learning to use a computer to perform some basic tasks or applications.

\section{FACTORS AFFECTING SUCCESSFUL IMPLEMENTATION OF COMPUTER STUDIES IN 9-YEAR BASIC EDUCATION}

In spite of the importance of computer education to national development, computer education still encounter numerous challenges, hence the need and demand for computer education still exists. This unfortunate factor in effective implementation of computer studies in 9-year basic education programme is attributed to the following factors:

1. Lack/insufficient Computer Laboratory: Most of the schools do not have computer laboratory. They are poorly equipped where it exists. For effective learning of computer, the students must be able to practicalise what they have learnt in the classroom. With laboratory, students who have difficulty in learning through the textbooks or classroom lessons would be able to understand more by being able to see it and practice it in laboratory. Reference [3] teaching and learning materials required to enable technology innovation to work should be easily available. In order to integrate computers into the school curriculum, there is need for all schools to have adequate supply of computers and other related resources. Without the hardware and software, it is impossible to implement changes that require such support and other teaching and learning materials.

2. Inadequate textbooks in the schools: Most of the schools do not have textbooks and if available there is no conducive environment such as the library where the students can have his/her private reading.

3. Lack of Motivation: For a student to have interest in computer he or she must be motivated. It is the function of the teacher to create interest of the computer in the student. Such interest can be situational or personal interest.
4. Poor school environment: Learning can effectively and efficiently provided when it is conducive. A conducive learning and teaching environment acts a factors to enhance learning of students/pupils. The school environment in most of our public schools is bad. Some students of urban areas have good conducive environment for learning while some do not. In some rural areas the classrooms are dilapidated or unavailable whereby some students do have their lesson under the trees.

5. Non-availability of instructional material and facilities: Reference [4] poised that inadequate material resources posed a serious challenge to science teacher because most of the schools are poorly equipped. In such a condition, teaching impedes knowledge and less development of the skills by the pupils. The use of equipment in teaching and learning situation will not only save teaching time and stimulate students interest but it will also increase retention of knowledge since most students remember what they see, heard and read longer than what they only read.

6. Insufficient or non-supply of electricity: It has been observed that some schools have been provided with electricity supply and many do not have. Mostly, those schools in the rural areas do not benefit from the introduction of computer studies in their curriculum because of lack of electricity supply. Recently, incessant power failure has greatly affected the use of computer in most schools, where they even have the computers.

7. Unqualified teachers: The quality of teachers has major influence in a sound computer education. Unfortunately, most schools are scarcely provided with qualified teachers. Most schools that has computer in their curricula usually have a computer teacher to a whole school.

8. Lack of incentive to motivate teachers: There is lack of incentive and poor or low remunerations to motivate teachers that are taking computer studies. Teachers are the most important factor that is needed in the study of the course; hence their low remunerations have hindered the study of computer education in Nigeria.

9. Non-commitment by the school managers: The implementation of Universal Basic Education requires dedicated leaders, or school managers. It requires someone who understands thoroughly the philosophy behind the policy who will give directions in order to ensure that the aims and objectives of the policy are realized. In some schools, the principal who is suppose to be the link between teachers and government, do not carry or communicate the needs to the appropriate quarters in time or, a time, not at all.

10. Content of the curriculum: The contents of the syllabus or curriculum are too complex and wide for the students at this level, hence it needs to be modified to enhance effective teaching and learning, however, the teaching strength are inadequate 
because of the population of the students/pupils especially in public schools. A curriculum should be a structure series that embraces purposeful experiences provided and directed by educational institutes to achieve pre-determined goals

11. Poor standard of living: Most individual has interest in acquiring skills and up-to-date knowledge of computer. They are interested in use and application of computers to enhance their standard of living. Due to their poverty and poor standard of living, the ability and the cost of either acquiring or engaging in the acquisition of knowledge and purchase of computer system is very poor, hence, these less privilege ones who suffered to get conventional education could not have the means of acquiring the computer education due to level of their financial position.

12. Poor funding: The practical application or usage of computer cannot be overemphasized. Poor funding of educational sector by the Government (State and Federal) has greatly affected the running and proper learning of computer education. Without funding there will not be proper learning, practical application and effectiveness of the teaching of the course.

13. Poor implementation of Government Policies: Government policies on education in the recent past have been worrisome. The poor or nonimplementation of these policies has hindered or marred the efficient and effective learning/teaching of computer education. The issue of delay in carrying out the policies, non implementation of these policies and bureaucratic bottle necks have hindered the proper implementation of computer education

\section{Statement Of The Problem Of The Study}

This study is to find factors that militate the successful implementation of computer studies in the 9-year Universal Basic of Education and to proffer solution to the factors identified. The researcher hoped that the study will benefit the students, teachers, school administrator and government in general so as to find means of solving those identified factors in order to successfully implement the study of computer in 9-year universal basic of education.

\section{Aims And ObJectives Of The Study}

Computer has been a means of communication and has continuously expanded the scope of the development but yet there has been a factor in the teaching, learning and implementation of the computer studies in the 9-year universal basic education program of the Federal Government of Nigeria. In view of this the research is to look into those factors that have hindered its successful implementation. Some of this could be attributed to instructional/infrastructure, poor funding, non-qualified teacher or the syllabus/curriculum been used.

\section{RESEARCH QUESTIONS}

1. What are the factors militating against successful implementation of Computer studies in 9-year universal basic of education?

2. What is the general perception of the students about the factors militating against successful implementation of computer studies in 9-year universal basic education (UBE) programme ?

\section{HYPOTHESES}

1. There is no significant difference in the perception of students on factors militating against successful implementation of computer studies in 9-year UBE programme based on gender

2. There is no significant difference between teachers and head teachers in the factors militating against successful implementation of computer education in 9-year UBE.

\section{Methodology}

The study covered five Junior Secondary Schools in Gwagwalada Area council of Federal Capital Territory, Abuja. The population of the study involves five teachers and one hundred and Fifty students.

The sampling techniques used for the research work is simple random selection. The sample involves Fifty Eight male students and Ninety Two female students. The research is a descriptive survey which involve administration of questionnaires to gather the relevant information from the respondents. The administration of the questionnaires was done with the help of one research assistant. The questionnaire was tested and validated through expert judgment and the coefficient of reliability was calculated as 0.72 . The data was analyzed using simple frequency count, percentage and t-test statistical analysis.

\section{RESUlts}

The Result of this research is presented as follows:

\section{Research Question 1}

What are the factors militating against successful implementation of Computer studies in universal basic of education

Table 1 shows the frequency count and sample percentage analysis on the factors militating against successful implementation of computer studies in 9-year UBE programme. The table further shows that seven items: a, c, e, f, $\mathrm{g}, \mathrm{h}$ and $\mathrm{j}$ had percentages greater than $50.00 \%$. This implies that the majority of the respondents agreed with the researchers on the factors itemized in the questionnaire. Lack of computer laboratory for 
of practical skills had the highest percentage of $75.33 \%$; followed by non-availability of instructional materials and facilities for teaching and learning computer education which had a percentage of $59.33 \%$.

Table 1. frequency count and percentage analysis of factors militating against successful implementation of Computer studies in 9-year universal basic of education

\begin{tabular}{|c|c|c|c|c|c|}
\hline $\mathrm{S} / \mathrm{N}$ & ITEMS & \multicolumn{2}{|l|}{ YES } & \multicolumn{2}{|c|}{$\mathrm{NO}$} \\
\hline & & $\mathrm{F}$ & $\%$ & $\mathrm{~F}$ & $\%$ \\
\hline a. & $\begin{array}{l}\text { lack/insufficient } \\
\text { computer laboratory for } \\
\text { acquisition of practical } \\
\text { skill }\end{array}$ & 113 & 75.33 & 37 & 24.67 \\
\hline b. & $\begin{array}{lr}\text { Poor } & \text { Academic } \\
\text { environment for } \\
\text { teaching and learning } \\
\text { computer education }\end{array}$ & 73 & 48.67 & 77 & 51.33 \\
\hline c. & $\begin{array}{l}\text { Non-Availability of } \\
\text { instructional material } \\
\text { and facilities for } \\
\text { teaching and learning } \\
\text { computer education }\end{array}$ & 89 & 59.33 & 61 & 40.67 \\
\hline d. & $\begin{array}{l}\text { Inadequate or outdated } \\
\text { computer textbooks in } \\
\text { the schools }\end{array}$ & 59 & 39.33 & 91 & 60.67 \\
\hline e. & $\begin{array}{lr}\text { Lack of } & \text { incentive to } \\
\text { motivate } & \text { teachers } \\
\text { toward } & \text { computer } \\
\text { education } & \end{array}$ & 81 & 54.00 & 69 & 46.00 \\
\hline f. & $\begin{array}{ll}\text { Availability } & \text { of } \\
\text { unqualified teachers in } \\
\text { schools }\end{array}$ & 79 & 52.67 & 71 & 47.33 \\
\hline g. & $\begin{array}{ll}\text { Poor funding for } \\
\text { procurement }\end{array}$ & 84 & 56.00 & 66 & 44.00 \\
\hline h. & $\begin{array}{l}\text { Poor implementation of } \\
\text { government policies on } \\
\text { computer education }\end{array}$ & 77 & 51.33 & 73 & 48.67 \\
\hline i. & $\begin{array}{l}\text { Complexity of UBE } \\
\text { curriculum content in } \\
\text { computer education }\end{array}$ & 53 & 35.33 & 97 & 64.67 \\
\hline j. & $\begin{array}{l}\text { Lack of technical skill } \\
\text { to teach computer } \\
\text { education in schools }\end{array}$ & 88 & 58.67 & 62 & 41.33 \\
\hline
\end{tabular}

However, three items (b,d and i) had their percentages lesser than $50 \%$. This means that the respondents disagreed with the researchers on the factor itemized in the questionnaire. The respondents indicated that poor academic environment for teaching and learning computer education; inadequate or outdated textbooks in the schools and complexity of UBE curriculum content in computer education were not factors militating against implementation of computer studies in 9-year UBE programme.

\section{Research Question 2}

What is the general perception of the students about the factors militating against successful implementation of computer studies in 9-year universal basic education (UBE) programme ?
Table 2: frequency count and percentage analysis of general perception of students and factors militating against successful implementation of computer studies in UBE programme.

\begin{tabular}{|c|c|c|c|c|c|}
\hline $\mathrm{S} / \mathrm{N}$ & ITEM & \multicolumn{2}{|l|}{ YES } & \multicolumn{2}{|l|}{$\mathrm{NO}$} \\
\hline & & $\mathrm{F}$ & $\%$ & $\mathrm{~F}$ & $\%$ \\
\hline a. & $\begin{array}{l}\text { The numerical strength } \\
\text { of UBE teachers is } \\
\text { adequate in school }\end{array}$ & 129 & 92.67 & 21 & 7.33 \\
\hline b. & $\begin{array}{l}\text { The aims \& objectives } \\
\text { of UBE program are } \\
\text { well understood by the } \\
\text { teachers }\end{array}$ & 127 & 84.67 & 23 & 15.33 \\
\hline c. & $\begin{array}{l}\text { The UBE teachers have } \\
\text { standard } \\
\text { accommodation and } \\
\text { conducive welfare }\end{array}$ & 143 & 95.33 & 7 & 4.67 \\
\hline d. & $\begin{array}{l}\text { The monitoring \& } \\
\text { supervision exercise is } \\
\text { regular }\end{array}$ & 145 & 96.67 & 5 & 3.33 \\
\hline e. & $\begin{array}{l}\text { The UBE teachers vary } \\
\text { their methods of } \\
\text { teaching }\end{array}$ & 97 & 64.67 & 53 & 35.33 \\
\hline f. & $\begin{array}{l}\text { The UBE program is a } \\
\text { way to eradicate } \\
\text { illiteracy among the } \\
\text { populace }\end{array}$ & 121 & 80.67 & 29 & 19.33 \\
\hline g. & $\begin{array}{l}\text { There are enough } \\
\text { integrated relevant } \\
\text { computer textbook in } \\
\text { the library }\end{array}$ & 87 & 58.00 & 63 & 42.00 \\
\hline h. & $\begin{array}{l}\text { The UBE teachers } \\
\text { improvised } \\
\text { instructional materials } \\
\text { when they are not } \\
\text { available }\end{array}$ & 91 & 60.67 & 59 & 39.33 \\
\hline i. & $\begin{array}{l}\text { Well equipped } \\
\text { computer laboratory for } \\
\text { practical is available in } \\
\text { schools }\end{array}$ & 37 & 24.67 & 113 & 75.33 \\
\hline j. & $\begin{array}{l}\text { Salary of UBE teachers } \\
\text { is being paid regularly } \\
\text { to motivate the } \\
\text { workforce }\end{array}$ & 83 & 55.33 & 67 & 44.67 \\
\hline
\end{tabular}

The analysis of the table 2 shows that the respondents had positive perception about the factors militating against successful implementation of computer studies in 9-year universal basic education (UBE) programme. The table also indicates that $70.67 \%$ of the respondents agreed with the factors itemized by the researcher and $29.33 \%$ marked NO in their responses. Based on these percentages, the findings indicated that UBE staff in the selected school had positive perception.

\section{Testing Of Hypotheses}

\section{Hypothesis 1}

There is no significant difference in the perception of students on factors militating against successful implementation of computer studies in 9-year UBE programme based on gender 
Table 3. T-test analysis of male and female students' perception on factors militating against successful implementation of computer studies in 9-year UBE programme.

\begin{tabular}{lllllll}
\hline Gender & $\mathbf{N}$ & $\mathbf{X}$ (Mean) & SD & Df & $\mathbf{C t}$. & $\begin{array}{l}\text { Critical } \\
\mathbf{t}\end{array}$ \\
\hline Male & 58 & 17.93 & 2.29 & 148 & -1.94 & 1.65 \\
& & & & & & \\
Female & 92 & 17.41 & 3.13 & & & \\
\hline $\mathbf{P = 0 . 0 5}$ & & & & & &
\end{tabular}

Table 3shows that male respondents had 17.93 and 2.29 of mean and standard deviation respectively; while the female respondents 17.41 and 3.13 of mean and standard deviation. The table shows the calculated value of -1.94 and critical value of 1.65 . Since the calculated value is lesser than critical value the hypothesis was accepted. Therefore, there is no significant difference in the perception of students on factors militating against successful implementation of computer studies in 9-year UBE programme based on gender

\section{Hypothesis 2}

There is no significant difference between teachers and head teachers in the factors militating against successful implementation of computer education in 9-year UBE.

Table 4. T-test analysis of teachers and head teachers on factors militating against successful implementation of computer studies in 9year UBE.

\begin{tabular}{|c|c|c|c|c|c|c|}
\hline Status & $\mathbf{N}$ & X (Mean) & SD & Df & Ct. & Critical $t$ \\
\hline Teachers & 5 & 1.80 & 0.40 & 8 & 0.47 & 2.31 \\
\hline $\begin{array}{l}\text { Head } \\
\text { Teachers }\end{array}$ & 5 & 1.60 & 0.49 & & & \\
\hline
\end{tabular}

Table 4 shows that teachers had 1.80 and 0.40 of mean and standard deviation respectively; while the head teachers had 1.60 and 0.49 of mean and standard deviation. The table shows the calculated value of 0.47 and critical value of 2.31. Since the calculated value is lesser than critical value the hypothesis was accepted. Therefore, there is no significant difference between teachers and head teachers in the factors militating against successful implementation of computer education in 9-year UBE.

\section{Discussions Of ThE RESUlts}

From table 1, the analysis statistically shows that majority of respondents agreed with factors militating against successful implementation of computer studies in 9-year Universal Basic of Education. This indicates that $75.33 \%$ of the respondents do not have sufficient computer laboratory for the acquisition of practical skills for the needed practical knowledge of the subject, nonavailability of instructional material and facilities for teaching and learning, lack complexity of UBE curriculum content and other factors itemized which show that computer utilization affect the student performance in UBE schools.

Table 2 shows that the respondents had positive perception about the factors militating against successful implementation of computer studies in 9-year universal basic education (UBE) programme.

The hypothesis postulated for gender comparison was rejected. Table 3 shows that there is no significant difference in the perception of respondents on factors militating against successful implementation of computer studies in 9-year UBE programme based on gender,

Table 4 results of the research shows that most of the respondents (teachers) were NCE holders. This clearly shows that NCE holders are the teachers mostly used in those UBE schools for teaching computer studies. The result obtained from analysis of the hypothesis indicated there is significant difference in the factors militating against successful implementation of computer education in 9-year UBE programme on the basis of qualification and hence it affect the overall performance of students in UBE schools.

\section{CONCLUSIONS}

The research was designed to investigate the factors militating against successful implementation of computer studies in 9-year Universal Basic Education (UBE) programme in Gwagwalada Area Council of Federal capital Territory (FCT) - Abuja, Nigeria. The study was a descriptive survey and questionnaire was used to collect relevant information. The data collected was analyzed using frequency count, simple percentage and t-test statistical analysis was used to test the null hypothesis postulated for the study.

The findings of this research indicated that the majority of the respondents agreed with the researchers on the factors militating against successful implementation of computer studies in the 9-year UBE programme as shown in table 1 . Also, table 2 revealed that the respondents had positive perception on the factors listed by the researcher.

The result of the hypotheses tested showed that there is no significant difference in the perception of students on factors militating against successful implementation of computer studies in 9-year UBE programme based on gender; and there is no significant difference between teachers and head teachers in the factors militating against successful implementation of computer education in 9-year UBE.

\section{RECOMMENDATIONS}

Based on the findings, the following recommendations were made: 
1. Electricity should be made available to power these computers. A solar or battery powered electricity can be made available where the current National Electricity grid (PHCN) is not adequate or cannot be reach.

2. A computer laboratory and facilities should be provided in all public schools. Also, Internet facilities should be made available to the teachers and the students in general to enhance their knowledge for research purpose and acquisition of up-to-date information.

3. Provision of accessories to repair and maintain the broken down or faulty computers.

4. Qualified and well trained teacher in Computer Education should be employed or recruited and asked to handle the teaching of computer. And where they are not available, the current teachers taking the computer should be encouraged to become trained and re-train.

5. The content of the syllabus or curriculum is been reviewed, rather when necessary by experts/organizations saddled with the responsibility of curriculum evaluation, such a body is Nigerian Educational Research Development Council (NERDC). Therefore, constant review of curriculum or syllabus in line with the current trends in Information and Communication Technology should be carried out without prejudice.

6. The teacher should be well motivated by giving them allowances that will stimulate them and to better onthe-job performance. Adequate and decent salary packages should be given to the teachers. Also, qualified teachers of Computer studies should be rewarded, commended and sponsored for further studies. Seminars/workshops should be organized for them in order to improve their knowledge due to global changes and development as it affects computer industry.

7. Instructional materials and equipment should be provided and used by the teacher to give the pupils clear vision of what they are learning.

8. Computer laboratories/rooms should be well furnished by provision of air conditions so as to control heat, dust and any other environmental hazard.

9. Those that have the ability or are willing to study or learn computer should be encourage and sponsored, most especially the less privilege ones that do not have the financial means.

10. The issue of poor implementation of government policies should be looked into and any delay or bureaucratic bottleneck should be removed. Any delay either caused by the officer/manager in charge should be sanctioned and make to face the consequences as a saboteurs. Policies that will favour the learning/teaching should be promulgated, introduced and vigorously pursued.

\section{REFERENCES}

[1] R. Bukaliya, and A.K. Mubika (2011). Teacher Competence in ICT: Implications for Computer Education in Zimbabwean Secondary Schools, International Journal of Social Sciences and Education. ISSN: 2223-4934 Volume: 1 Issue: 4 October 2011.

[2] Federal Republic of Nigeria (2004): National Policy on Education (NPE): N.E.R.D.C. Press Yaba Lagos Nigeria.

[3] F. Y. Odera (2011) Emerging Issues in the Implementation of Computer Technology into Kenyan Secondary School Classrooms. International Journal of Science and Technology Volume 1 No.6, December 20. Retrieved from on the 18th July, 2014 http://ejournalofsciences.org/archive/vol1no6/vollno6_12 .pdf .

[4] L.A. Kurawa (2008): The Challenges of a Science Teacher in UBE programmes. A journal of Science Education.

[5] M. Lakkala, L. Ilomaki and A. Kantosalo, (2011) Which areas of digital competence are important for a teacher? International Journal of Social Sciences and Education ISSN: 2223-4934 Volume: 1 Issue: 4 October 2011.

[6] B.T. Lau and C.H. Sim (2008). Exploring the extent of ICT adoption among secondary school teachers in Malaysia. An International Journal of Computing and ICT Research, Vol. 2, No. 2, Dec., 2008 Retrieved from http://www.ijcir.org/volume2- number2/article3\%201936.pdf. on the 27th July, 2014.

[7] Nigerian Educational Research Development Council (2007): 9-year basic Education Curriculum. Computer studies for JSS 1-JSS 3. NERDC, Abuja.

[8] R. Oliver (2011). The role of ICT in higher education for the $21^{\text {st }}$ Century: ICT as a change agent for education. Retrieved on $26^{\text {th }}$ July, 2014 from www.citiseerx.ist.ed.

[9] S.V. Patil (2012). The Role of ICT in education sector. Lokavishkar International E-Journal, ISSN 2277-727X, Vol-I, Issue-IV, Oct-Nov-Dec2012.

[10] N.A. Yekini, J.O. Adigun and M.M. Rufai (2012). ICT "Tools" to improve quality assurance in Africa Educational System (Nigeria as a case study). Retrieved from

http://journal.info.unlp.edu.ar/journal/journal32/papers/JC ST-Apr12-2.pdf. On the $2^{\text {nd }}$ September, 2014.

[11] A, Yadan (2013). "Improve Abstract Reasoning in Computer Introductory Courses". Journal of I.J. Modern Education and Computer Sciences (MECS). Published online January 2013 in MECS (http://www.mecspress.org/) DOI: 10:5815/ijmecs.2013.01.02. pg 14.

[12] N.D. Oye, M.C. Obi, T.N. Mohd and A. Bernice (2012). "Guidance and Counseling in Nigerian Secondary Schools: The Role of ICT". Journal of I.J. Modern Education and Computer Sciences (MECS). Published online August 2012 in MECS (http://www.mecspress.org/) DOI: 10:5815/ijmecs.2012.08.04. pg 30.

[13] A. Ajay, M. Sripati (2014) "Studies on ICT usage in the Academic Campus Using Educationak Data Mining". Journal of I.J. Modern Education and Computer Sciences (MECS). Published online June 2014 in MECS (http://www.mecs-press.org/) DOI: 10:5815/ijmecs.2014.06.02.pg 11.

[14] P.G. Abbas, L. Lai-Mei and N.I Hairul (2013) "Teachers' Use of Technology and Constructivism”. Journal of I.J. Modern Education and Computer Sciences (MECS). Published online May 2013 in MECS (http://www.mecspress.org/) DOI: 10:5815/ijmecs.2013.04.07. pg 54.

[15] R.T. Tolorunleke (2012). "A panacea for Human Capacity Building for Teacher Education". A paper Presented at $4^{\text {th }}$ International Conference of Trans African 
University and Research Development Network (TANRDN). Published by International Institute for Empirical Research and Sustainable Development (IIERSD).

[16] M. Dominic, S. Francis and A. Pilomenraj (2014) "ELearning in Web 3.0". Journal of I.J. Modern Education and Computer Sciences (MECS). Published online February 2014 in MECS (http://www.mecs-press.org/) DOI: 10:5815/ijmecs.2014.02.02.pg 9.

[17] P.G. Abbas, L. Lai-Mei and N.I Hairul (2013) "The Relationship Between Emotional Intelligence and Students' Attitude Towards Computers: A Study on Polytechnic Engineering Students". Journal of I.J. Modern Education and Computer Sciences (MECS). Published online September 2012 in MECS (http://www.mecs-press.org/)
DOI: 10:5815/ijmecs.2012.09.02. pg 14.

\section{Author's profile}

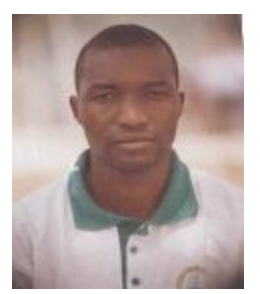

Garba Suleiman is a staff of FCT College of Education Zuba, Abuja, Computer Science Department. He is currently undergoing is Masters (M.Tech) programme in Computer Science at Federal University of Technology, Minna. $\mathrm{He}$ had been teaching for over 7 years in Secondary School before joining FCT College of Education, Zuba, Abuja-Nigeria in 2007.

How to cite this paper: Garba Suleiman, Solomon A. Adepoju, John K. Alhassan,"Factors Militating against Successful Implementation of Computer Studies in 9-Year Universal Basic Education (UBE) Programme",IJMECS, vol.7, no.5, pp.50-58, 2015.DOI: 10.5815/ijmecs.2015.05.07 